WellBeing International

WBI Studies Repository

$2-2009$

\title{
Health Professionals' Roles in Animal Agriculture, Climate Change, and Human Health
}

\author{
Aysha Z. Akhtar \\ The Washington Center for Clinical Research \\ Michael Greger \\ The Humane Society of the United States \\ Hope Ferdowsian \\ The Humane Society of the United States \\ Erica Frank \\ University of British Columbia
}

Follow this and additional works at: https://www.wellbeingintlstudiesrepository.org/acwp_aafhh

Part of the Agribusiness Commons, Animal Studies Commons, and the Business Law, Public Responsibility, and Ethics Commons

\section{Recommended Citation}

Akhtar, A. Z., Greger, M., Ferdowsian, H., \& Frank, E. (2009). Health professionals' roles in animal agriculture, climate change, and human health. American Journal of Preventive Medicine, 36(2), 182-187.

This material is brought to you for free and open access by WellBeing International. It has been accepted for inclusion by an authorized administrator of the WBI Studies Repository. For more information, please contact wbisr-info@wellbeingintl.org.

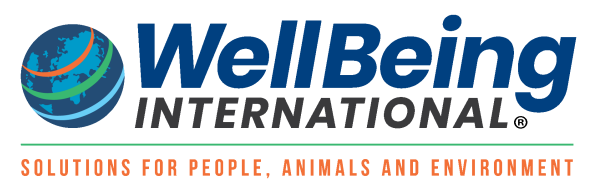




\title{
Health Professionals' Roles in Animal Agriculture, Climate Change, and Human Health
}

\author{
Aysha Z. Akhtar, MD, MPH, ${ }^{1}$ Michael Greger, $M D,{ }^{2}$ Hope Ferdowsian, $M D,{ }^{1}$ Erica Frank, $\mathrm{MD}^{3}$ \\ ${ }^{1}$ The Washington Center for Clinical Research \\ ${ }^{2}$ The Humane Society of the United States \\ ${ }^{3}$ The School of Population and Public Health, University of British Columbia
}

\section{CITATION}

Akhtar, A. Z., Greger, M., Ferdowsian, H., \& Frank, E. (2009). Health professionals' roles in animal Agriculture, climate change, and human health. American Journal of Preventive Medicine, 36(2), 182-187.

\begin{abstract}
What we eat is rapidly becoming an issue of global concern. With food shortages, the rise in chronic disease, and global warming, the impact of our dietary choices seems more relevant today than ever. Globally, a transition is taking place toward greater consumption of foods of animal origin, in lieu of plantbased diets. With this transition comes intensification of animal agriculture that in turn is associated with the emergence of zoonotic infectious diseases, environmental degradation, and the epidemics of chronic disease and obesity. Health professionals should be aware of these trends and consider them as they promote healthier and more environmentally-sustainable diets.
\end{abstract}

\section{Introduction}

Over 9 billion land animals are slaughtered for food annually in the U.S., ${ }^{1,2}$ approximately 1 million per hour. The U.S. is home to only about $5 \%$ of the global population but produces nearly $15 \%$ of the world's meat supply, ${ }^{3}$ and the average American consumes 110 pounds of red meat and 74 pounds of poultry per year. ${ }^{4}$ Global demand for meat has increased substantially in recent decades. Between 1975 and 1990, per capita meat consumption increased an estimated $1.4 \%$ per year. ${ }^{5}$ World meat production is expected to double by $2020,{ }^{6}$ in part due to national and international regulations that allow animal agribusiness to externalize costs and to aggressive corporate marketing campaigns. ${ }^{7-10}$ For example, the U.S. Federal Government subsidy system and food assistance programs heavily promote the production and distribution of meat and dairy products, ${ }^{11-17}$ over plant-based foods.

Recently an investigation of a California dairy cow slaughter plant by the Humane Society of the U.S. (HSUS) documented the abuse and slaughter of cows too sick or injured to walk, leading to the recall of 143 million pounds of beef in February 2008, the largest in U.S. history. ${ }^{18}$ The investigation raised considerable concern about the safety of the meat supply, including inadequate regulatory oversight by the U.S. Department of Agriculture (USDA), partly due to the high throughput of animals slaughtered for food.

\section{Climate Change and Environmental Degradation}

As a result of the steady rise in animal-product promotion and demand, traditional farming practices in the latter half of the last century were replaced in the U.S. largely by immense, intensive animal operations; in 
the developing world, they are being replaced at a rate of more than $4 \%$ a year. ${ }^{6}$ The industrialization of animal agriculture is an important contributor to global environmental degradation and climate change. ${ }^{19}$

Animal agriculture accounts for $37 \%, 65 \%$, and $64 \%$ of anthropogenic methane, nitrous oxide, and ammonia emissions, respectively, from ruminant fermentation, livestock waste, fertilizer use and other factors. ${ }^{20}$ Methane and nitrous oxide have 23 and 296 times, respectively, the global warming potential of CO2. 20 In 2006, the UN Food and Agriculture Organization (FAO) declared that animal agriculture contributes $18 \%$ of annual anthropogenic greenhouse gas emissions, measured in $\mathrm{CO}_{2}$-equivalents, more than that of the worldwide transportation sector ${ }^{20}$ The public health effects of climate change are already being felt around the world and the UN Intergovernmental Panel on Climate Change projects that they will worsen considerably. ${ }^{21-26}$

Animal agriculture constitutes $30 \%$ of the total land surface, the largest use of land by humans. ${ }^{20}$ Thirty- $^{2}$ three percent of total arable land is used to produce feedcrops, ${ }^{20}$ with energy input that far outweighs the output. Approximately $70 \%$ of previously forested land in the Latin American Amazon is used as grazing pastures, with the remainder being used largely for feedcrop production. ${ }^{20}$ Annually in the U.S., 45 million tons of plant protein are used to produce 7.5 million tons of animal protein. ${ }^{27}$ Most of this plant protein could instead be consumed directly by humans and could, in part, alleviate some growing concerns about a global food shortage.

Animal agriculture consumes $70 \%$ of the fresh water and contributes extensively to land, air, and water pollution. ${ }^{20}$ Pesticides and fertilizers, including manure, may contaminate waterways. In the U.S., animal agriculture is responsible for $37 \%$ of pesticide use and $32 \%$ and $33 \%$, respectively, of the nitrogen and phosphorus loads found in fresh water sources. ${ }^{20}$ Surveys in North Carolina and lowa found substantial increases in asthma symptoms in children residing near industrial pig operations and decreased quality of life measures in surrounding communities. ${ }^{28-30}$ The combined environmental impact of animal agriculture has led the FAO to declare in 2006 that "the livestock sector emerges as one of the top two or three most significant contributors to the most serious environmental problems, at every scale from local to global." ${ }^{20}$

\section{Emerging and Re-Emerging Infectious Diseases}

In 2004, the WHO, the World Organization for Animal Health, and the FAO reported that the increasing global demand for animal protein in the human diet, associated with the expansion and intensification of animal agriculture, long-distance live-animal transport and other factors, were in part responsible for the emergence of zoonotic diseases. ${ }^{31}$ Industrial agriculture practices have been blamed for the emergence of bovine spongiform encephalopathy, multidrug-resistant foodborne bacteria, and highly pathogenic strains of avian influenza. ${ }^{32}$

An estimated 76 million Americans are stricken with a foodborne illness every year. ${ }^{33}$ Worldwide, foodborne microbial disease kills an estimated 20 million people annually, with animal products topping the list of causes. ${ }^{34}$ The global rise in the incidence of foodborne diseases is attributed to greater consumption of animal products, the intensification of farm operations, and rising temperatures. ${ }^{35,36}$

Annually, more than a ton of farm-animal manure is produced per capita in the U.S. ${ }^{37}$ Farm-animal manure is the source of more than 100 zoonotic pathogens, ${ }^{38}$ which may contaminate food and water supplies. Manure-contaminated irrigation water, for example, was likely the source of the largest recorded outbreak of Escherichia coli O157:H7, affecting more than 7000 schoolchildren in Japan. ${ }^{39}$ 
Under conditions ripe for zoonotic pathogen emergence and transmission, such as the high-density confinement of farm animals under unhygienic conditions, ${ }^{6}$ farm animal growth rates may be impaired in light of the infectious load to which they are exposed. This may be mitigated by a constant influx of growth-promoting antibiotics. ${ }^{40}$ Half of all U.S. antimicrobials are fed to farm animals. ${ }^{41,42}$ The mass use of clinically significant antibiotics in animal agriculture selects for drug-resistant pathogens and mobile genetic elements carrying resistance determinants that may be responsible for the majority of the increase in antibiotic-resistant human isolates reported. ${ }^{43,44}$

\section{Chronic Diseases}

Historically, chronic diseases, including obesity, have plagued the developed world, whereas developing countries have been more affected by communicable diseases. However, obesity and chronic diseases are increasingly a concern in developing nations. ${ }^{10}$ An estimated $65 \%$ of U.S. adults are overweight or obese, ${ }^{45}$ and globally, more than 1 billion adults are overweight. ${ }^{46}$ Especially concerning is the increasing global prevalence of childhood obesity. ${ }^{46}$ Obesity increases the risk for diabetes, arthritis, asthma, hypertension, and hypercholesterolemia. ${ }^{47}$ Worldwide, cardiovascular disease, cancer, and diabetes are three of the four main causes of death. ${ }^{48}$

The worldwide transition from a predominantly plant-based diet to a diet high in meat has been identified as a noteworthy contributor to the rise in chronic disease. ${ }^{10,49}$ Animal products are the main source of saturated fats that promote cardiovascular disease ${ }^{49}$ and the sole source of cholesterol intake. Comparative studies reveal that those who follow plant-based diets generally have lower weights than those who do not, ${ }^{50,51}$ even across ethnic groups. ${ }^{50}$ While not conclusive, evidence suggests that the increase in worldwide obesity and diabetes may in part be associated with increased animal-product consumption, in addition to decreased exercise and other factors. ${ }^{10}$

The classic study by Armstrong and Doll ${ }^{52}$ revealed significant association between meat consumption and colon cancer incidence in over 25 countries. Studies in Japan revealed a rising incidence in colorectal cancer with greater adoption of Western dietary habits and consumption of meat, milk, eggs, and fats and oils. ${ }^{53,54}$ Other studies revealed similar associations between rising meat consumption in Asian countries and colon cancer incidence and/or mortality. ${ }^{55,56}$ Although confounding factors must also be considered, these and other studies collectively provide strong evidence of the causal link between meat and colorectal cancer. ${ }^{57-59}$ In 2007, the World Cancer Research Fund and the American Institute for Cancer Research panel report concluded that there was convincing evidence to limit red meat intake, completely avoid processed meat, and follow a plant-based diet to reduce the overall risk for cancer. ${ }^{59}$

Consumption of various animal products is also associated with increased risk for other cancers. Endometrial cancer risk is associated with increased intake of total energy, fat, and protein from animal sources. ${ }^{60}$ A meta-analysis found an increased endometrial cancer risk with increased meat, particularly red meat, consumption. ${ }^{61}$ Dairy-product consumption has been associated with prostate cancer ${ }^{62-64}$; the European Prospective Investigation into Cancer and Nutrition study of 142,251 men found that high intake of dairy calcium and protein increased the risk of prostate cancer. ${ }^{65}$ Calcium from nondairy foods was not associated with increased cancer risk. In recent studies, breast cancer risk has been associated with higher intake of processed meat, total meat, and/or red meat, ${ }^{66-69}$ and with higher intakes of total and saturated fats. ${ }^{69}$

Healthcare costs attributable to meat consumption are substantial, estimated in the U.S. at between \$29 billion and $\$ 61$ billion per year, in 1992 dollars. ${ }^{70}$ In contrast, many studies suggest that those who consume plant-based diets have decreased risk, mortality, and/or progression of cardiovascular 
disease,${ }^{71-73}$ diabetes, ${ }^{74}$ certain cancers, ${ }^{75-77}$ and obesity. ${ }^{78,79}$ Diets high in legumes, whole grains, fruits, and vegetables appear to be protective against these chronic diseases. ${ }^{80-82}$

\section{What Healthcare Providers Can Do}

Physicians and other healthcare providers can play a critical role in promoting healthier food options and reversing the trend toward greater livestock production. Healthcare providers can help accomplish this in three main ways: as advocates, as providers, and as role models.

As evidence-based advocates, healthcare providers can provide medical input into federal policies that affect nutrition and health. The American Public Health Association (APHA), the American Medical Association, and the President's Cancer Panel of the National Cancer Institute have highlighted the importance to the obesity epidemic of federal food policy, as well as the importance of physician and public health leadership in federal nutrition policy reform. ${ }^{8,83,84}$ Currently, U.S. agricultural policy disparately promotes animal products, in contradiction with the U.S. Dietary Guideline's emphasis on plant-based foods. A calculated $73 \%$ of over $\$ 60$ billion in federal commodities payments for domestic food consumption between 1995 and 2005 supported the production of meat, eggs, and dairy, either directly or indirectly through feedcrop supports. ${ }^{11-17}$ Less than $0.5 \%$ of federal subsidies is allocated to fruits and vegetables.

After the California slaughter plant investigation and meat recall of February 2008, public food safety concerns were especially heightened, since a large fraction of the meat that was recalled had already been distributed to school lunch programs.18 Surplus agricultural products, largely animal products high in fat and cholesterol, are distributed through school lunch and other food assistance programs. An estimated 100,000 schools receive these commodities, possibly contributing to the fact that approximately $80 \%$ of elementary and secondary schools violate limits on total and saturated fat content. ${ }^{85,86}$

International studies have demonstrated that changes in agricultural subsidy policy can mitigate rising chronic disease rates. In Poland, the withdrawal of large animal-product subsidies led to decreased saturated fat intake and increased fruit and vegetable intake, followed by a subsequent decrease in ischemic heart disease mortality. ${ }^{87}$ After long periods of increases, mortality from heart disease and stroke decreased by $25 \%$ and 10\%, respectively, between 1991 and 1994 among those aged 45- 64 . Between 1986 to 1990 and 1994, there was a 23\% decrease in animal fat availability, 48\% increase in vegetable fat availability, and an almost $50 \%$ increase in importation of certain fruits. In Eastern European countries in 2002, substantial decline in cardiovascular mortality was associated with increased consumption of plant oils rich in alphalinolenic acid. ${ }^{88}$

In addition to involvement in food policy, healthcare providers should have a coordinated voice in environmental policy. The APHA has a policy calling for a moratorium on factory farms ${ }^{89}$ Other physician and healthcare groups could follow suit. Recently, the U.S. Environmental Protection Agency proposed that livestock farms be exempt from reporting emissions of ammonia, hydrogen sulfide and other pollutants. ${ }^{90}$ Input from healthcare providers is needed to prevent such regressions in environmental protections that may otherwise pose adverse public health consequences.

As healthcare providers, all physicians, nurses, and physicians assistants can incorporate nutrition counseling into routine care. When physicians advise their patients about nutrition, incidence of chronic diseases may decline..$^{91-94}$ Despite the potential of counseling to improve dietary practices, many primary care physicians never include nutrition or dietary counseling in their patient visits, or include only 
perfunctory counseling. ${ }^{95-98}$ Medical societies can facilitate the incorporation of routine nutrition counseling by advocating for greater physician reimbursement for such care.

Finally, as individuals, healthcare providers can serve as examples and leaders when they alter their own lifestyle behaviors. One of the least exploited and most significant and consistent counseling predictors is the positive effect of a physician's healthy personal practices on his or her clinical prevention-related practices. ${ }^{99-103}$ Specifically, physicians' healthy dietary practices positively affect their clinical nutrition counseling attitudes ${ }^{99}$ and practices ${ }^{91,99,102,103}$; and U.S. medical students find nutrition counseling more relevant if they consume more fruits and vegetables. ${ }^{104}$

Health professionals can set an example by consuming fewer animal products at home and at work, and by demanding healthier plant-based options in hospital cafeterias, doctors' and nurses' lounges, and at professional conferences and meetings. The APHA and the Johns Hopkins Center for a Livable Future offer prime examples of how meatless meals can be promoted. ${ }^{105,106}$ Through the work of Health Care Without Harm coalition, over 122 hospitals in the U.S. have signed a pledge to offer healthier food items to visitors, patients, and staff. ${ }^{107}$ Health professionals can also stress nutrition education in Continuing Medical Education courses.

Given the animal agriculture sector's considerable role in environmental degradation, zoonotic disease emergence, and chronic disease promotion, reducing livestock production and promoting healthy plantbased diets should be a global health priority. Healthcare providers can, individually and collectively, play a significant role in ensuring healthy and environmentally sustainable nutrition policies and practices.

\section{References}

1. USDA. Livestock slaughter 2003 summary. usda.mannlib.cornell.edu/usda/nass/LiveSlauSu//2000s/2004/LiveSlauSu-05-04-2004.txt.

2. USDA. Poultry slaughter 2003 annual summary. 2004. usda.mannlib.cornell.edu/usda/nass/PoulSlauSu//2000s/2004/PoulSlauSu-03-08-2004.txt.

3. Food and Agricultural Organization of the United Nations. Production of meat and share of the world. www.fao.org/statistics/yearbook/vol_1_1/pdf/b02.pdf.

4. U.S Census Bureau. Statistical abstract of the United States. 2008. www.census.gov.

5. Trostle R. Global agricultural supply and demand: factors contributing to the recent increase in food commodity prices. WRS-0801. Economic Research Service/USDA, 2008.

6. Pearson J, Salman MD, BenJabara K, et al. Global risks of infectious animal diseases. Council for Agricultural Science and Technology, Issue Paper No. 28., 2005.

7. Elinder LS. Obesity, hunger, and agriculture: the damaging role of subsidies. $\mathrm{Br}$ Med $\mathrm{J}$ 2005;331:1333- 6.

8. American Public Health Association. Toward a healthy, sustainable food system. Policy number 200712. APHA, 2007. www.apha.org/advocacy/policy/policysearch/default.htm?id=1361.

9. Chopra M, Darnton-Hill I. Tobacco and obesity epidemics: not so different after all? $\mathrm{Br}$ Med J 2004;328:1558-60.

10. Popkin BM, Du S. Dynamics of the nutrition transition toward the animal foods sector in China and its implications: a worried perspective. J Nutr 2003;133:3898S-3906S.

11. Environmental Working Group. Environmental Working Group's farm subsidy database. Top programs in the United States, 1995-2006. farm.ewg.org/farm/region.php?fips $=00000$.

12. United Soybean Board. 2001 soy stats. www.soystats.com.

13. World Resources Institute, EarthTrends. Nutrition: grain fed to livestock as a percent of total grain consumed. 
earthtrends.wri.org/searchable_db/index.php?theme=8\&variable_ID=348\&action= select_countries.

14. Good D. Corn: a record large crop. Grain Price Outlook 2003, No. 7. www.ideals.uiuc.edu/bitstream/2142/1379/2/101703.pdf.

15. Sustainable Agriculture Network. Opportunities in agriculture. Diversifying cropping systems. Thomas Jefferson Agricultural Institute. www.sare.org/publications/diversify/diversify.pdf

16. Office of Industries, U.S. International Trade Commission. Industry and trade summary: grains (cereals). USITC Publication 3350, September 2000.

hotdocs.usitc.gov/docs/pubs/industry_trade_summaries/pub3350.pdf.

17. Leibtag E. Corn prices near record high, but what about food costs? Amber Waves 2008;6. www.ers.usda.gov/amberwaves/february08/features/cornprices.htm.

18. Brown D. USDA orders largest meat recall in U.S. history. The Washington Post 2008 Feb 18.

19. Koneswaran G, Nierenberg D. Global farm animal production and global warming: impacting and mitigating climate change. Environ Health Perspect 2008;116:578-82.

20. Food and Agriculture Organization of the United Nations. Livestock's long shadow: environmental issues and options. Rome: Food and Agriculture Organization of the United Nations, 2006.

21. Frumkin H, Hess J, Luber G, Malilay J, McGeehin M. Climate change: the public health response. Am J Public Health 2008;98:435-45.

22. Shea KM, American Academy of Pediatrics Committee on Environmental Health. Global climate change and children's health. Pediatrics 2007;120:e1359-67.

23. Bernstein L, Bosch P, Osvaldo C, et al. Climate change 2007: synthesis report. Summary for policymakers. An assessment of the Intergovernmental Panel on Climate Change. www.ipcc.ch/pdf/assessment-report/ar4/syr/ar4_syr_spm.pdf.

24. Frumkin $\mathrm{H}$, McMichael AJ, Hess JJ. Climate change and the health of the public. Am J Prev Med 2008:35:401-2.

25. Kinney PL. Climate change, air quality, and human health. Am J Prev Med 2008:35:459-67.

26. St. Louis ME, Hess JJ. Climate change: impacts on and implications for global health. Am J Prev Med 2008:35:527- 41.

27. Pimentel D. Livestock production and energy use. In: Matsumura R, ed. Encyclopedia of energy. San Diego: Elsevier, 2004.

28. Mirabelli MC, Wing S, Marshall SW, Wilcosky TC. Asthma symptoms among adolescents who attend public schools that are located near confined swine feeding operations. Pediatrics 2006;118:e66-75.

29. Wing S, Wolf S. Intensive livestock operations, health and quality of life among Eastern North Carolina residents. Environ Health Perspect 2000; 108:233- 8.

30. Merchant JA, Naleway AL, Svendsen ER, et al. Asthma and farm exposures in a cohort of rural lowa children. Environ Health Perspect 2005;113:350-6.

31. WHO, Food and Agriculture Organization of the United Nations, World Organization for Animal Health (WHO/FAO/OIE). Report of the WHO/FAO/OIE joint consultation on emerging zoonotic diseases, 2004.

32. Greger M. The human/animal interface: emergence and resurgence of zoonotic infectious diseases. CRC Crit Rev Microbiol 2007;33:243-99.

33. Mead PS, Slutsker L, Dietz V, et al. Food-related illness and death in the United States. Emerg Infect Dis 1999;5:607-25.

34. Delgado C, Rosegrant M, Steinfeld H, Ehui S, Courbois C. Livestock to 2020, the next food revolution. Food, agriculture, and the environment discussion paper 28, for the International Food Policy Research Institute, Food and Agriculture Organization of the United Nations, and the International Livestock Research Institute, 1999.

35. Adams M, Motarjemi Y. Basic food safety for health workers. Geneva: WHO Press, 1999. 
36. McMichael AJ, Haines A, Slooff R, Kovats S, eds. Change and human health. Geneva: WHO, World Meteorological Organization, United States Environmental Program, 1996.

37. Environmental Protection Agency. National pollutant discharge elimination system permit regulation and effluent limitation guidelines and standards for concentrated animal feeding operations (CAFOs); Final Rule, 68 Fed. Reg. 7176, 7180, February 12, 2003.

38. Walton JR, White EG, Communicable diseases resulting from storage handling, transport and land spreading of manure. Luxembourg: Office for Official Publications of the European Communities, 1981.

39. Michino H, Araki K, Minami S, et al. Massive outbreak of Escherichia coli O157:H7 infection in schoolchildren in Sakai City Japan, associated with consumption of white radish sprouts. Am J Epidemiol 1999;150:787-96.

40. Office of Technology Assessment (OTA). Drugs in livestock feed: volume 1. Technical Report. Washington DC: U.S. Government Printing Office, 1979.

41. Antimicrobial resistance: issues and options. In: Harrison PF, Lederberg J, eds. Forum on emerging infections, Institute of Medicine. Washington DC: National Academy Press, 1998.

42. PEW: Pew Charitable Trusts. Putting meat on the table: industrial farm animal production in America. The Pew Charitable Trusts and Johns Hopkins Bloomberg School of Public Health. A report of the Pew Commission on industrial farm animal production, 2008.

43. Smith DL, Dushoff J, Morris JG. Agricultural antibiotics and human health. PLoS Medicine 2005;2:e232.

44. Tollefson L, Fedorka-Cray PJ, Angulo FJ. Public health aspects of antibiotic resistance monitoring in the USA. Acta Vet Scand Suppl 1999;92:67-75.

45. CDC. National Center for Health Statistics factsheet. Prevalence of overweight and obesity among adults: United States, 2003-2004. www.cdc.gov.

46. World Health Organization factsheet: obesity and overweight. www.who.int/dietphysicalactivity/publications/facts/obesity/en.

47. Mokdad AH, Ford ES, Bowman BA, et al. Prevalence of obesity, diabetes, and obesity-related health risk factors, 2001. JAMA 2003;289:76-9.

48. Yach D, Hawkes C, Gould CL, Hofman KJ. The global burden of chronic diseases. Overcoming impediments to prevention and control. JAMA 2004;291:2616-22.

49. Walker P, Rhubart-Berg P, McKenzie S, Kelling K, Lawrence RS. Public health implications of meat production and consumption. Public Health Nutr 2005;8:348-56.

50. Berkow SE, Barnard N. Vegetarian diets and weight status. Nutr Rev 2006;64:175-88.

51. Melby CL, Hyner GC, Zoog B. Blood pressure in vegetarians and non-vegetarians: a cross-sectional analysis. Nutr Res 1985;5:1077-82.

52. Armstrong B, Doll R. Environmental factors and cancer incidence and mortality in different countries, with special reference to dietary practices. Int J Cancer 1975;15:617-31.

53. Kuriki K, Tajima K. The increasing incidence of colorectal cancer and the preventive strategy in Japan. Asian Pac J Cancer Prev 2006;7:495-501.

54. Kuriki K, Tokudome S, Tajima K. Association between type II diabetes and colon cancer among Japanese with reference to change in food intake. Asian Pac J Cancer Prev 2004;5:28-35.

55. Tominaga S, Kuroishi T. An ecological study on diet/nutrition and cancer in Japan. Int J Cancer 1997;S10:2-6.

56. Lee SI, Moon HY, Kwak JM, et al. Relationship between meat and cereal consumption and colorectal cancer in Korea and Japan. J Gastroenterol Hepatol 2008;23:138-40.

57. Chao $\mathrm{A}$, Thun $\mathrm{MJ}$, Connell $\mathrm{CJ}$, et al. Meat consumption and risk of colorectal cancer. JAMA 2005;293:172-82.

58. Cross AJ, Leitzmann MF, Gail MH, Hollenbeck AR, Schatzkin A, Sinha R. A prospective study of red and processed meat intake in relation to cancer risk. PLoS Medicine 2007;4:e325. 
59. World Cancer Research Fund/American Institute for Cancer Research. Food, nutrition, physical activity and the prevention of cancer: a global perspective. Washington DC: AICR, 2007.

60. Xu W-H, Dai Q, Xiang Y-B, et al. Nutritional factors in relation to endometrial cancer: a report from a population-based case-control study in Shanghai China. Int J Cancer 2007;120:1776-81.

61. Bandera EV, Kushi LH, Moore DF, Gifkins DM, McCullough ML. Consumption of animal foods and endometrial cancer risk: a systematic literature review and meta-analysis. Cancer Causes Control 2007;18:967-88.

62. Mitrou PN, Albanes D, Weinstein SJ, et al. A prospective study of dietary calcium, dairy products and prostate cancer risk (Finland). Int J Cancer 2007;120:2466-73.

63. Chan JM, Stampfer MJ, Ma J, Gann PH, Gaziano JM, Giovannuci EL. Dairy products, calcium, and prostate cancer risk in the Physician's Health Study. Am J Clin Nutr 2001;74:549-54.

64. Kurahashi N, Inoue M, Iwasaki M, Sasazuki S, Tsugane AS, Japan Public Health Center-Based Prospective Study Group. Dairy product, saturated fatty acid, and calcium intake and prostate cancer in a prospective cohort of Japanese men. Cancer Epidemiol Biomarkers Prev 2008;17:9307.

65. Allen NE, Key TJ, Appleby PN, et al. Animal foods, protein, calcium and prostate cancer risk: the European perspective investigation into cancer and nutrition. Br J Cancer 2008;6:1574-81.

66. Taylor EF, Burley VJ, Greenwood DC, Cade JE. Meat consumption and risk of breast cancer in the UK Women's Cohort Study. Br J Cancer 2007;96:1139-46.

67. Linos E, Willett WC, Cho E, Colditz G, Frazier LA. Red meat consumption during adolescence among premenopausal women and risk of breast cancer. Cancer Epidemiol Biomarkers Prev 2008;17:2146-51.

68. Cho E, Chen WY, Hunter DJ, et al. Red meat intake and risk of breast cancer among premenopausal women. Arch Intern Med 2006;166:2253-9.

69. Boyd NF, Stone J, Vogt KN, Connelly BS, Martin LJ, Minkin S. Dietary fat and breast cancer risk revisited: a meta-analysis of the published literature. Br J Cancer 2003;89:1672-85.

70. Barnard ND, Nicholson A, Howard JL. The medical costs attributable to meat consumption. Prev Med 1995;24:646-55.

71. Ornish D, Scherwitz LW, Billings $\mathrm{JH}$, et al. Intensive lifestyle changes for reversal of coronary heart disease. JAMA 1998;280:2001-7.

72. Kwok TK, Woo J, Ho S, Sham A. Vegetarianism and ischemic heart disease in older Chinese women. J Am Coll Nutr 2000;19:622-7.

73. Key TJ, Fraser GE, Thorogood M, et al. Mortality in vegetarians and non-vegetarians: a collaborative analysis of 8300 deaths among 76,000 men and women in five prospective studies. Public Health Nutr 1998; 1:33-41.

74. Barnard ND, Cohen J, Jenkins DJ, et al. A low-fat vegan diet improves glycemic control and cardiovascular risk factors in a randomized clinical trial in individuals with type 2 diabetes. Diabetes Care 2006;29:1777-83.

75. Saxe GA, Major JM, Nguyen JY, Freeman KM, Downs TM, Salem CE. Potential attenuation of disease progression in recurrent prostate cancer with plant-based diets and stress reduction. Integr Cancer Ther 2006;5:206-13.

76. Ornish D, Weidner G, Fair WR, et al. Intensive lifestyle changes may affect the progression of prostate cancer. J Urol 2005;174:1065-9.

77. Cui X, Dai Q, Tseng M, Shu XO, Gao YT, Zheng W. Dietary patterns and breast cancer risk in the shanghai breast cancer study. Cancer Epidemiol Biomarkers Prev 2007;16:1443-8.

78. Key TJ, Davey GK, Appleby PN. Health benefits of a vegetarian diet. Proc Nutr Soc 1999;58:271-5.

79. Ornish D, Brown SE, Sherwitz LW, et al. Can lifestyle changes reverse coronary heart disease? Lancet 1990;336:129-33.

80. Slavin J. Why whole grains are protective: biological mechanisms. Proc Nutr Soc 2003;62:129-34. 
81. Slavin JL, Jacobs D, Marquart L, Wiemer K. The role of whole grains in disease prevention. J Am Diet Assoc 2001;101:780-5.

82. Everitt AV, Hilmer SN, Brand-Miller JC, et al. Dietary approaches that delay age-related diseases. Clin Interv Aging 2006;1:11-31.

83. American Medical Association House of Delegates: H-150.944, combating obesity and health disparities, 2007. www.ama-assn.org.

84. President's Cancer Panel, National Cancer Institute, USDHHS. Promoting healthy lifestyles: policy, program, and personal recommendations for reducing cancer risk. 2006 -2007 Annual Report, August 2007.

85. Fox Mk, Crepinsek MK, Connor P, Battaglia M, McKinne P. School nutrition dietary assessment study-II. Summary of findings. Alexandria VA: U.S. Department of Agriculture, Food and Nutrition Service, Office of Analysis, Nutrition and Evaluation., 2001.

www.fns.usda.gov/oane/menu/published/cnp/files/sndaiifindsum.htm.

86. Bhattacharya J, Currie J, Haider SJ. Evaluating the impact of school nutrition programs. Final report. E-FAN-04-008, U.S. Department of Agriculture, Economic Research Service, 2004. www.ers.usda.gov/publications/efan04008.

87. Zatonski WA, McMichael AJ, Powles JW. Ecological study of reasons for sharp decline in mortality from ischemic heart disease in Poland since 1991. Br Med J 1998;316:1047-51.

88. Zatonski W, Campos H, Willett W. Rapid declines in coronary heart disease mortality in Eastern Europe are associated with increased consumption of oils rich in alpha-linolenic acid. Eur $\mathrm{J}$ Epidemiol 2008;23:3-10.

89. American Public Health Association. Precautionary moratorium on new concentrated animal feed operations. APHA policy statement number 20037. 11/18/2003. www.apha.org/advocacy/policy/policysearch/default.htm?id=1243.

90. EPA proposal on livestock emissions causes stink. The High Plains/Midwest Agriculture Journal 2008 Jan 9.

91. Ammerman AS, DeVellis RF, Carey TS, et al. Physician-based diet counseling for cholesterol reduction: current practices, determinants, and strategies for improvement. Prev Med 1993;22:96109.

92. Hadden DR, Blair AL, Wilson EA, et al. Natural history of diabetes presenting at age 40-69 years: a prospective study of the influence of intensive dietary treatment. Q J Med 1986;59:579-98.

93. Horrocks PM, Blackmore R, Wright AD. A long-term follow-up of dietary advice in maturity-onset diabetes: the experience of one centre in the UK Prospective Study. Diabet Med 1987;4:241-4.

94. U.S. Preventive Services Task Force. Behavioral counseling in primary care to promote a healthy diet: recommendations and rationale. Am Fam Physician 2003;67:2573-6. www.aafp.org/afp/20030615/us.html

95. Kushner RF. Barriers to providing nutrition counseling by physicians: a survey of primary care practitioners. Prev Med 1995;24:546-52.

96. Russell NK, Roter DL. Health promotion counseling of chronic-disease patients during primary care visits. Am J Public Health 1993;83:979-82.

97. Anis NA, Lee RE, Ellerbeck EF, Nazir N, Greiner KA, Ahluwalia JS. Direct observation of physician counseling on dietary habits and exercise: patient, physician, and office correlates. Prev Med 2004;38:198-202.

98. Frank E, Wright EH, Serdula MK, Elon LK, Baldwin G. U.S. women physicians' personal and clinical nutrition-related practices. Am J Clin Nutr 2002;75:326-32.

99. Sciamanna CN, DePue JD, Goldstein MG, et al. Nutrition counseling in the promoting cancer prevention in primary care study. Prev Med 2002;35:437-46.

100. Cummings KM, Giovino G, Sciandra R, Koenigsberg M, Emont SL. Physician advice to quit smoking: who gets it and who doesn't. Am J Prev Med 1987;3:69 -75. 
101. Lewis CE, Clancy C, Leake B, Schwartz JS. The counseling practices of internists. Ann Intern Med 1991;114:54 - 8 .

102. Hyman DJ, Maibach EW, Flora JA, Fortmann SP. Cholesterol treatment practices of primary care physicians. Public Health Rep 1992;107:441- 8.

103. Frank E, Rothenberg R, Lewis C, Belodoff BF. Correlates of physicians' prevention-related practices. Findings from the women physicians' health study. Arch Fam Med 2000;9:359-67.

104. Spencer EH, Frank E, Elon LK, Hertzberg VS, Serdula MK, Galuska DA. Predictors of nutrition counseling behaviors and attitudes among U.S. medical students. Am J Clin Nutr 2006;84:655-62.

105. American Public Health Association. Climate change: our health in the balance. Healthy climate pledge. 2008. www.ecdh.org/documents/livingthehealthlyclimatepledge.pdf.

106. Johns Hopkins Bloomberg School of Public Health, Center For a Livable Future Programs. Eating for the future. Meatless Monday Campaign, Inc. www.jhsph.edu/clf/PDF\%20Files/Info_sheet_programs_eat.pdf.

107. Harvey J. Menu of change: healthy foods in health care. A 2008 survey of healthy food in health care pledge hospitals. Health Care Without Harm, 2008. www.noharm.org 